\title{
Does Socio-demographic Variables Matter in Explaining Issues and Challenges in Islamic Microfinance? Evidence from Malaysia
}

\section{Marhanum Che Mohd Salleh¹, Salina Kassim², and Siti Nadhirah Kassim ${ }^{3}$}

${ }^{1}$ Assistant Professor at Department of Finance, Kulliyyah of Economics \& Management Sciences, International Islamic University Malaysia

${ }^{2}$ Associate Professor at Institute of Islamic Banking and Finance, Kulliyyah of Economics \& Management Sciences, International Islamic University Malaysia

${ }^{3}$ Master Student at Institute of Islamic Banking and Finance, Kulliyyah of Economics \& Management Sciences, International Islamic University Malaysia

\section{Abstract}

Purpose - In line with the wide acceptance of the microfinance industry globally, Islamic microfinance has also evolved rapidly in the past years to cater for the demand for Shariah-compliant microfinancing schemes. Despite this, the industry is facing

Corresponding Author: Marhanum Che Mohd Salleh marhanum@iium.edu.my

Received: 10 February 2019 Accepted: 14 March 2019 Published: 28 March 2019

Publishing services provided by Knowledge E

(c) Marhanum Che Mohd Salleh et al. This article is distributed under the terms of the Commons Attribution License, which permits unrestricted use and redistribution provided that the original author and source are credited.

Selection and Peer-review under the responsibility of the ICIEBP Conference Committee. various issues and challenges from both the clients and microfinance institutions. This study aims to identify the issues and challenges faced by different demographic background of microentrepreneurs receiving Islamic microfinancing from Amanah Ikhtiar Malaysia (AIM). Methodology- It adopts the quantitative research methodology where primary data is collected using survey questionnaires administered on 393 women entrepreneurs who are currently clients of AIM's Islamic microfinance scheme located in Selangor. The descriptive and cross-tabulation analyses are applied in efforts to understand the influence of socio-demographic factors (age, education level, duration with AIM, and times of receiving financing) on the following issues: cost of repayment, financing period, amount of financing, distance to AIM center, group lending mechanism, discipline among members, problematic group members, and consultation services. Findings - The study finds that clients with different socio-demographic factors perceived the issues differently, suggesting an influential role of clients' demographic factors on the microfinance intervention. Practical implications - These findings have important implications to the microfinance industry in terms of further improving their products that are tailor-made to the socio-demographic characteristics of their clients. Originality - This research taken views of AIM's microfinance recipients which were woman entrepreneurs in Selangor directly through a survey. Results of the research would be useful to AIM to enhance their products and services in future.

Keywords: Islamic microfinance, socio-demography, Islamic finance, Amanah Ikhtiar Malaysia

\section{G OPEN ACCESS}




\section{Introduction}

Today, microfinance has become a widely accepted tool for poverty alleviation around the globe. It empowers the poor and makes them economically independent; by having access to finance, small entrepreneurs are able to expand their businesses, support their families, and improve their socio-economic status. In Malaysia, microfinance industry came into existence in 1986 with the launching of 'Project Ikhtiar', an action research project initiated by the University Science of Malaysia (USM) which examined the suitability of the Grameen Model in reducing poverty in the context of Malaysia (Saad \& Duasa, 2011). The project was made possible through funding from Malaysian Islamic Economic Development Foundation (YPEIM), Asia Pacific Development Centre (APDC) and the Selangor State Government. Following the success of the project, the country's first two microfinance institutions (MFIs) were established in 1987, namely Amanah Ikhtiar Malaysia (AIM) and Yayasan Usaha Maju (YUM), with AIM providing the microfinance services throughout the country, while YUM targets the low-income group particularly in Sabah. Being placed under the purview of the Ministry of Agriculture and Agro-based Industry Malaysia, among the objectives of YUM is to provide loans to the poor and hard-core poor and to support government efforts to alleviate poverty in Sabah (Yayasan Usaha Maju 2017).

Subsequently in November 1998, in the aftermath of the Asian financial crisis which hit the country in 1997, another MFI was established, namely the Economic Fund for National Entrepreneurs Group (or TEKUN). TEKUN's process of borrowers' selection is rather different compared to AIM and YUM as it reaches out to wider community by granting loans to both poor and not-so-poor entrepreneurs. Being subjected under the supervision of Ministry of Agriculture and Agro-Based Malaysia, TEKUN aims to provide quick and easy loans to the Bumiputra community as well as Indian entrepreneurs. Since then, there has been significant growth of innovative and progressive entrepreneurs from all over Malaysia due to the financing disbursed by TEKUN.

Financing schemes offered by TEKUN ranging from RM500 up to RM 50,000, involving small-medium scale entrepreneurial activities to those aged between 18 and 65 years old. Unlike YUM and AIM, TEKUN grants more flexible lending contracts to its borrowers as it gives reasonable grace periods to borrowers mainly in agricultural activities. As an example, it grants a one-year grace period for fruit and vegetable farming as well as cattle farming activities while six months for poultry farming and fishponds. TEKUN considers grace period in accordance to the harvesting cycles in the borrowers' businesses (TEKUN 2009). 
In terms of lending system, while YUM and TEKUN implement individual lending system, AIM adopts a group-based lending system following the Grameen model. Even though group lending system is proven to ensure a higher loan re-payment rate, it is not feasible to be implemented by YUM due to geographical constraints of its borrowers. It is difficult for them to meet each other often despite residing in the same village, hence making peer monitoring ineffective in this situation (Mokhtar et al. 2012).

The country's microfinance ecosystem further evolved and now consists of both nonbanking institutions (NBIs) as well as banking institutions engaging in the provision of financial assistance to the low-income group. Recent data on the poverty level indicates that together, these institutions have played an effective role in alleviating the poverty in the country. Examples of the banking institutions providing microfinance products include Bank Simpanan Nasional, Bank Rakyat, Agro Bank and CIMB Bank. As for NBls (including the non-government organisations - NGOs), credit unions and government agencies), several MFIs operating under this category namely AIM, YUM, TEKUN, People's Credit Cooperation (KKR), Council of Trust to the Bumiputera (MARA), Farmers Organization Authority (FOA), Federal Land Development Authority (FELDA) and Permodalan Usahawan Nasional Berhad (PUNB) (Nawai and Shariff, 2011). Specifically, for agricultural sectors, notable institutions that have been providing microcredit are Agrobank, FELDA and agro-based cooperative societies (Haque et. al., 2015).

Despite the encouraging development of the microfinance industry in Malaysia, the industry is still facing various issues and challenges. This study aims to further explore the issues and challenges faced by the micro-entrepreneurs of different demographic background who are clients of AIM. By administering survey questionnaires on 393 clients of AIM, the study aims to analyse the influence of socio-demographic factors, namely age, education level, duration with AIM, and times of receiving financing on the following issues: cost of repayment, financing period, amount of financing, distance to AIM center, group lending mechanism, discipline among members, problematic group members, and consultation services. This study offers an area of novelty as the role of demographic factors on the specific issues of microfinance has never been explored before. Findings of this study have important implications to the microfinance industry in terms of further improving the microfinance products that are tailor-made to the sociodemographic characteristics of their clients in efforts to ensure the effectiveness of the microfinance program. 


\section{Provision of Microfinance: Case of Amanah Ikhtiar Malaysia}

\subsection{Lending mechanisms}

Being the largest Islamic MFI in Malaysia, Amanah Ikhtiar Malaysia (AIM) which operates as an NGO is also considered as one of the most prominent Islamic MFIs in the world. Despite being an NGO, the source of funds for AIM comes in the form of interestfree government financing, grants and soft loans through allocations made under the various Malaysia Plans (Mason et al., 2015). This is in line with the government efforts to eradicate poverty in the country.

Lending mechanism adopted by AIM revolves around the provision of collateral-free credit to be paid back in small instalments on weekly basis by the clients, known as Sahabat (in the Malaysian language, which carries the meaning of "close friend"). AIM model is distinctive in comparison to the classic microcredit model is that it aspires to create a sustainable change among its borrowers. Without the need for collateral, guarantors or any legal action against defaulters, there exists a lot of risks in this lending system. Thus, to mitigate the risks, a group-based microcredit program was established to enable collateral-deprived borrowers to form group of five people in order to guarantee each other's repayments although loans are provided on individual basis. According to Mason, Azmi and Madden (2015), this collective responsibility creates a sense of peer pressure and accountability among group members, leading to high repayment rates. Indeed, the label of being "Sahabat" or close friends to each other in the group carries the sense of responsibility and togetherness, with the sense of belonging among each of the group members motivate them to help one another in improving their lives. Al Mamun, Malarvizhi, Hossain and Abdul Wahab (2011) further describe the selection process of eligible candidate to become Sahabat is based on gross average monthly household income. Households with gross monthly income below the national poverty line income (PLI) would be considered eligible to apply for the financing schemes.

Accordingly, to ensure the repayment of financing is done according to the schedule, meetings with all Sahabats are conducted on a weekly basis at meeting centers where attendance is made compulsory to all members to ensure smooth operations throughout the tenure. Any arising issues faced by Sahabats would be addressed and discussed accordingly by AIM fieldworkers during the meeting. An effective delivery system is crucial to ensure AlM's sustainability and thus far, enforced weekly center meeting 
has brought impactful results in enhancing client's social networking and bondage. In addition, a series of training are conducted to harness entrepreneurial skills among the clients to ensure optimal utilization of resources. To achieve an optimal usage of resources, a wide array of services were offered inclusive of financial education, entrepreneurship training, value chain support and social services to the Sahabats.

The microfinance system developed by AIM also primarily seeks to nurture the Sahabats to sustain their businesses and subsequently establish themselves as small and medium-level entrepreneurs. Staying true to its objective to reduce poverty, AIM launched Urban Micro Finance Program in 2008 to expand AlM's micro-financing approach to the poor and lower income group in urban areas. However, unlike the rural microcredit program, Urban Micro Finance Program do not select their clients based on PLI, rather clients with a household income below RM 2000 were selected, an indication that the program is designed to also support non-poor households ( $\mathrm{Al}$ Mamun et. al., 2011).

\subsection{Products}

The main objective of AIM's microcredit schemes is to grant benevolent loans for economic activities. As an Islamic MFI, AIM employs the Shariah concepts of Qard (benevolent loan), Ujrah (service fees) as well as Tawarruq (commodity murabahah) in its financing contracts and schemes. Mason et al. (2015) reports that there are three major economic financing schemes offered by AIM namely i-Mesra loan, i-Srikandi loan and i-Wibawa. The most basic financing scheme is the i-Mesra scheme (up to RM 10,000) which targets to finance economic projects expected to garner favourable returns to the clients. The grace period of repayment is between 12 to 100 weeks. The i-Srikandi scheme is offered to individuals with potentially viable and successful projects with amount of financing ranging from RM 12,000 to the maximum amount of RM 20,000 whilst its repayment period ranges from 12 to 150 weeks. The i-wibawa scheme, which is specifically for individuals subscribing to the i-Mesra or i-Srikandi scheme, provides soft loans to those needing additional capital for the purpose of undertaking seasonal projects with maximum disbursement amount of RM 5,000 to be paid back within 6 months.

In addition to aforementioned economic schemes, other non-economic financing schemes offered include i-Bistari scheme (education loan), i-Sejahtera scheme (housing/multipurpose loan), i-Penyayang scheme (recovery loan for those with repayment problems) and the i-Emas scheme (loan for individuals aged 75 years old and above). 
The i-Sejahtera scheme ranges between RM 1000 up to RM 10,000 while the i-Bistari provides financing from RM 1,000 up to RM 5,000 with both having a grace period of 12 to 100 weeks. The i-Penyayang is given to Sahabats who are at default risks due to project failure, natural disaster or health problems amounting to RM 5000 with the same grace period as other financing schemes. On the other hand, the i-Emas scheme offers a maximum disbursement amount of RM 2,000 to the senior citizens. All financing assistances are covered by micro-insurance except for i-Emas (Mason et al., 2015).

\subsection{Issues and challenges facing AIM}

Despite the success of AIM in extending its outreach to the poor, they are facing several issues and challenges that should be addressed. Due to their heavy reliance on governmental grants, sustainability is an ongoing issue faced by AIM which negatively impacts outreach. This dependence on government funding further causes it to be vulnerable to political intervention and as a result, their involvement in community investment activities are limited (Mokhtar et al., 2012). There is a legal clause in The Malaysia Banking and Financial Act 1989 which legally restricts non-bank institutions from taking deposits from clients. Bounded by that legal restriction, AIM products and services lack diversity and are limited to only credit facilities. This impedes their growth, ability to realise their full potential and be self-sustainable.

In a study by Mokhtar et al. (2012), it was discovered that the group lending mechanism adopted by AIM contributed to a high repayment rate compare to other MFIs such as YUM and TEKUN. However, the study observed that other group members were left with no other option but to settle the outstanding amount due on behalf of their defaulted group member as it would affect their ability to obtain financing in the future. Thus, it can be deduced that the high repayment rate recorded by AIM is at the expense of individuals who paid their dues to maintain a good track record. This causes injustice among the borrowers and raises questions on the effectiveness of the group lending mechanism practised by AIM. Further, Nawai and Bashir (2007) in their research found that the microfinance programs by AIM had credit leakage problems. To illustrate, AIM clients who are no longer eligible to receive financing as they are not considered poor household, still received financing from AIM. This calls for a strict and thorough screening of eligible clients to ensure financing are given out only to qualified borrowers to ensure program objectives are met. 


\section{Methodology}

In achieving the research objective, this study adopts quantitative methodology where data is collected via survey based on closed-ended questionnaires distributed to 393woman micro-entrepreneurs under Amanah Ikhtiar Malaysia at Ulu Selangor branch. Simple descriptive and cross-tabulation analyses was conducted to observe the issues and challenges encountered by the micro-entrepreneurs based on their various demographic background namely level of education, duration with AIM and times of receiving the financing. There were eight issues and challenges identified in this research (cost of repayment, period, amount of financing, distance to AIM center, group lending mechanism, problematic group members, low discipline among members, and consultation services based on past studies and observation. The respondents were basically asked about their agreement on these issues based on their experience dealing with AIM. Detail analysis of the results is presented in next section.

\section{Findings}

\subsection{Background of woman microentrepreneurs}

Table 1 below presents detailed profiling of the women micro-entrepreneurs participated in this research. In terms of age, majority of them are 30 years old and above (92.9 percent) and mostly married (83.7 percent). Most of the respondents have received secondary education (72.9 percent), with only few of them managed to study at higher learning institution for the degree level (11 respondents). Of the total respondents, nearly 97 percent are self-employed with only 3 percent have permanent jobs in the public and private sectors. Of those who are self-employed, majority become micro-entrepreneurs through financial assistance from AIM (80 percent).

Majority of the respondents are repeat clients as shown by the response of duration becoming AIM member. In particular, half of them (197 respondents) have dealt with AIM more than 3 years and only few were less than a year (49 respondents). It is because of the nature of the financing which can be added (value) and extended (duration) in case of good record of payment from the microentrepreneurs. Therefore, 56 percent of them have been given financing more than 3 times. Overall, the respondents are found to have enough experience receiving and dealing with AIM to conduct their businesses. Therefore, their opinion and experiences are relevant and important for this research in 
order to enhance the AIM financing scheme as well as the microfinance industry as a whole.

TABLE 1: Background of Respondents.

\begin{tabular}{|c|c|c|c|}
\hline \multicolumn{2}{|c|}{ Demographic Information } & \multirow{2}{*}{$\begin{array}{c}\text { Frequency } \\
4\end{array}$} & \multirow{2}{*}{$\begin{array}{c}\text { Percentage } \\
\text { (\%) } \\
1.0\end{array}$} \\
\hline Age & 20 years old and & & \\
\hline & below 21-29 years old & 24 & 6.1 \\
\hline & $30-39$ years old & 101 & 25.7 \\
\hline & 40-49 years old & 129 & 32.8 \\
\hline & Above 50 years old & 135 & 34.4 \\
\hline & Total & 393 & 100.0 \\
\hline \multirow[t]{4}{*}{ Marital Status } & Single & 19 & 4.8 \\
\hline & Married & 329 & 83.7 \\
\hline & Single parent & 45 & 11.5 \\
\hline & Total & 393 & 100.0 \\
\hline \multirow[t]{7}{*}{ Level of Education } & Primary School & 28 & 7.1 \\
\hline & Secondary & 286 & 72.8 \\
\hline & Certificate & 28 & 7.1 \\
\hline & Diploma & 39 & 9.9 \\
\hline & Degree & 11 & 2.8 \\
\hline & Others & 1 & 0.3 \\
\hline & Total & 393 & 100.0 \\
\hline \multirow[t]{8}{*}{ Occupation } & Permanent (government sector) & 3 & 0.8 \\
\hline & Permanent (private sector) & 9 & 2.3 \\
\hline & Self-employed (own capital) & 64 & 16.3 \\
\hline & Self-employed (AIM capital) & 224 & 57.0 \\
\hline & $\begin{array}{l}\text { Permanent government and } \\
\text { self-employed (AIM) }\end{array}$ & 13 & 3.3 \\
\hline & $\begin{array}{l}\text { Permanent private and } \\
\text { self-employed (AIM) }\end{array}$ & 14 & 3.6 \\
\hline & Self-employed (own and AIM capital) & 66 & 16.8 \\
\hline & Total & 393 & 100.0 \\
\hline \multirow[t]{6}{*}{ Duration with AIM } & $<1$ year & 49 & 12.6 \\
\hline & $1-2$ years & 70 & 18.0 \\
\hline & $2-3$ years & 73 & 18.8 \\
\hline & $>3 y e a r s$ & 197 & 50.6 \\
\hline & No answer & 4 & - \\
\hline & Total & 393 & 100.0 \\
\hline \multirow[t]{5}{*}{ Times receiving AIM financing } & 1 time & 59 & 15.0 \\
\hline & 2 times & 49 & 12.5 \\
\hline & 3 times & 65 & 16.5 \\
\hline & $>3$ times & 220 & 56.0 \\
\hline & Total & 393 & 100.0 \\
\hline
\end{tabular}




\subsection{Issues facing women microentrepreneurs}

Table 2 shows the responses given by the women microentrepreneurs who are clients of AIM. The respondents indicated their level of agreement on a scale of 1 to 5 , with one being strongly disagree with the statement made on the particular issue and 5 indicates strogly agree. There are eight issues highlighted to be considered by the respondents, namely (i) cost of repayment, (ii) repayment period, (iii) amount of financing, (iv) distance to AIM center, (v) effectiveness of group lending mechanism, (vi) views on problematic group members, (vii) low discipline among members, and (viii) lack of consultation services.

TABLE 2: Issues and Challenges Experienced by Respondents.

\begin{tabular}{|c|c|c|c|c|c|c|c|c|}
\hline \multirow[t]{2}{*}{ No. } & \multirow[t]{2}{*}{ Issues and challenges } & \multicolumn{5}{|c|}{ Level of Agreement (\%) } & \multirow[t]{2}{*}{ Mean } & \multirow{2}{*}{$\begin{array}{l}\text { Standard } \\
\text { deviation }\end{array}$} \\
\hline & & 1 & 2 & 3 & 4 & 5 & & \\
\hline 1 & $\begin{array}{l}\text { High and burdensome cost } \\
\text { of financing }\end{array}$ & 15.3 & 51.7 & 14.2 & 16.8 & 2.0 & 2.39 & 1.00 \\
\hline 2 & $\begin{array}{l}\text { Very short repayment } \\
\text { period }\end{array}$ & 10.2 & 53.9 & 13.7 & 19.3 & 2.8 & 2.51 & 1.00 \\
\hline 3 & $\begin{array}{l}\text { Inadequate amount of } \\
\text { financing }\end{array}$ & 10.7 & 56.5 & 13.5 & 17.8 & 1.5 & 2.43 & 0.95 \\
\hline 4 & $\begin{array}{l}\text { Far distance of centers } \\
\text { resulting in high cost of } \\
\text { travelling }\end{array}$ & 17.8 & 55.2 & 10.9 & 14.5 & 1.5 & 2.27 & 0.97 \\
\hline 5 & $\begin{array}{l}\text { Ineffective group lending } \\
\text { mechanism }\end{array}$ & 12.7 & 47.6 & 14.2 & 22.6 & 2.8 & 2.55 & 1.06 \\
\hline 6 & $\begin{array}{l}\text { Problematic group } \\
\text { member(s) in repayment of } \\
\text { financing }\end{array}$ & 10.7 & 32.3 & 13.0 & 30.5 & 13.5 & 3.04 & 1.26 \\
\hline 7 & $\begin{array}{l}\text { Low discipline among } \\
\text { group members }\end{array}$ & 7.1 & 35.6 & 16.0 & 34.1 & 7.1 & 2.98 & 1.13 \\
\hline 8 & $\begin{array}{l}\text { Absence of financial } \\
\text { consultation service }\end{array}$ & 8.4 & 42.2 & 22.4 & 23.2 & 3.8 & 2.72 & 1.03 \\
\hline
\end{tabular}

Based on responses, it is observed that the financed microentrepreneurs were not experienced much issues with AIM along the period of financing. However, it is worth noting that there were few issues that need attention by AIM as shared by the respondents. Referring to scale 1-5 that represent the agreement of the respondents on the issues listed by researchers, nearly half of them were agree that they have issue with their group members in repayment of financing (44 percent agree and strongly agree) as well as low discipline of the members (41.2 percent). As a consequence, a few of them felt dissatisfies with the group lending mechanism practiced by AIM (25.4 percent). However, looking from positive side, this research found that the group lending 
mechanism still effective based on majority view and they have no issue with the cost of financing, period of repayment, amount of financing, distance of AIM centers, as well as financial consultation service provided by AIM. Accordingly, given that repayment and discipline have become the issue among the entrepreneurs, next section will investigate further these issues among the entrepreneurs of different educational background, duration of experiences with AIM and times of receiving the financing.

\subsection{Linking the socio-demographic variables with issues and challenges}

\section{Issue 1a: Problematic group member(s) in repayment of financing and different educational background}

The first issue that was clearly agreed by majority of the respondents is with regards to repayment of financing by group members. In this context, the group lending mechanism that was practiced by AIM would need the entrepreneurs to be in a group and choose their own members ( 5 members in a group) for future financing repayment responsibility. This mechanism thus requires all the members to be committed and responsible to pay their financing and at the same time ensure other members do the same. The problem would exist in case of any of the members fail to pay the financing amount (weekly) where this would affect the whole group members to pay the weekly financing amount. This issue is further examined via cross-tabulation analysis in order to investigate view of the entrepreneurs of different educational background. As in Table 3a below, 44 percent of the total respondents have an agreement that they have dealt with this issue before. In addition, even though majority of the respondents in this research were from group of secondary school, the issue of prepayment of financing is mostly agreed by the respondents from degree group (63.7 percent agree and strongly agree) and followed by those from group of primary school (50 percent agree and strongly agree). Therefore, it can be concluded that those who received higher education would concern more on this issue compare to the lower education groups. It can be interpreted that this issue most probably done by the lower education groups especially the secondary level of education (majority respondents). 
TABLE 3: Results of Cross-tabulation Analysis

\begin{tabular}{|c|c|c|c|c|c|c|c|c|}
\hline \multicolumn{9}{|c|}{ Problematic group member(s) in repayment of financing } \\
\hline & & & $\begin{array}{l}\text { Strongly } \\
\text { disagree }\end{array}$ & Disagree & Unsure & Agree & $\begin{array}{l}\text { Strongly } \\
\text { agree }\end{array}$ & \\
\hline \multirow[t]{15}{*}{ Education } & $\begin{array}{l}\text { Primary } \\
\text { school }\end{array}$ & Count & 2 & 11 & 1 & 9 & 5 & 28 \\
\hline & & $\begin{array}{l}\% \text { within } \\
\text { Education }\end{array}$ & $7.1 \%$ & $39.3 \%$ & $3.6 \%$ & $32.1 \%$ & $17.9 \%$ & $100.0 \%$ \\
\hline & & $\%$ of Total & $0.5 \%$ & $2.8 \%$ & $0.3 \%$ & $2.3 \%$ & $1.3 \%$ & $7.1 \%$ \\
\hline & $\begin{array}{l}\text { Secondary } \\
\text { school }\end{array}$ & Count & 31 & 91 & 40 & 87 & 37 & 286 \\
\hline & & $\begin{array}{l}\% \text { within } \\
\text { Education }\end{array}$ & $10.8 \%$ & $31.8 \%$ & $14.0 \%$ & $30.4 \%$ & $12.9 \%$ & $100.0 \%$ \\
\hline & & $\%$ of Total & $7.9 \%$ & $23.2 \%$ & $10.2 \%$ & $22.1 \%$ & $9.4 \%$ & $72.8 \%$ \\
\hline & Certificate & Count & 4 & 8 & 4 & 8 & 4 & 28 \\
\hline & & $\begin{array}{l}\% \text { within } \\
\text { Education }\end{array}$ & $14.3 \%$ & $28.6 \%$ & $14.3 \%$ & $28.6 \%$ & $14.3 \%$ & $100.0 \%$ \\
\hline & & $\%$ of Total & $1.0 \%$ & $2.0 \%$ & $1.0 \%$ & $2.0 \%$ & $1.0 \%$ & $7.1 \%$ \\
\hline & Diploma & Count & 4 & 15 & 4 & 11 & 5 & 39 \\
\hline & & $\begin{array}{l}\% \text { within } \\
\text { Education }\end{array}$ & $10.3 \%$ & $38.5 \%$ & $10.3 \%$ & $28.2 \%$ & $12.8 \%$ & $100.0 \%$ \\
\hline & & $\%$ of Total & $1.0 \%$ & $3.8 \%$ & $1.0 \%$ & $2.8 \%$ & $1.3 \%$ & $9.9 \%$ \\
\hline & Degree & Count & 1 & 1 & 2 & 5 & 2 & 11 \\
\hline & & $\begin{array}{l}\% \text { within } \\
\text { Education }\end{array}$ & $9.1 \%$ & $9.1 \%$ & $18.2 \%$ & $45.5 \%$ & $18.2 \%$ & $100.0 \%$ \\
\hline & & $\%$ of Total & $0.3 \%$ & $0.3 \%$ & $0.5 \%$ & $1.3 \%$ & $0.5 \%$ & $2.8 \%$ \\
\hline \multirow[t]{2}{*}{ Total } & & Count & 42 & 127 & 51 & 120 & 53 & 393 \\
\hline & & $\%$ of Total & $10.7 \%$ & $32.3 \%$ & $13.0 \%$ & $30.5 \%$ & $13.5 \%$ & $100.0 \%$ \\
\hline
\end{tabular}

Issue 1b: Problematic group member(s) in repayment of financing and duration with AIM

The issue of repayment of financing among AIM members is further emphasised in terms of different duration of experiences among the entrepreneurs dealt with AIM. There were four different periods captured in this research (less than a year, 1-2 years, 2-3 years, and more than 3 years) and most of the entrepreneurs' understudy have dealt with AIM more than 3 years. Overall, in terms of duration dealing with AIM, the agreement on this issue were mostly came from the respondents that have dealt with AIM between 2-3 years (54.77 percent agree and strongly disagree). It is followed by those who have dealt with AIM for a period of 1-2 years and more than 3 years. This research therefore found that the tendency for the microentrepreneurs to observe the issue of repayment of financing among the AIM members were seen after two years of subscription. Hence, this issue was rarely observed by the microentrepreneurs that 
have received the financing less than a year. As a consequence, the longer period of financing, the longer experience that they will have with AIM, and as a result, the higher chances of having problematic group members will happened. Please refer to Table $3 b$ for details on the results.

TABLE 4: Results of Cross-tabulation Analysis.

\begin{tabular}{|c|c|c|c|c|c|c|c|c|}
\hline \multicolumn{9}{|c|}{ Problematic group member(s) in repayment of financing } \\
\hline & & & $\begin{array}{l}\text { Strongly } \\
\text { disagree }\end{array}$ & Disagree & Unsure & Agree & $\begin{array}{c}\text { Strongly } \\
\text { agree }\end{array}$ & \\
\hline \multirow{12}{*}{$\begin{array}{l}\text { Duration } \\
\text { with AIM }\end{array}$} & $<1$ year & Count & 6 & 13 & 11 & 14 & 5 & 49 \\
\hline & & $\begin{array}{l}\% \text { within } \\
\text { Duration_AIM }\end{array}$ & $12.2 \%$ & $26.5 \%$ & $22.4 \%$ & $28.6 \%$ & $10.2 \%$ & $100.0 \%$ \\
\hline & & $\%$ of Total & $1.5 \%$ & $3.3 \%$ & $2.8 \%$ & $3.6 \%$ & $1.3 \%$ & $12.6 \%$ \\
\hline & $1-2$ years & Count & 6 & 27 & 5 & 21 & 11 & 70 \\
\hline & & $\begin{array}{l}\% \text { within } \\
\text { Duration_AIM }\end{array}$ & $8.6 \%$ & $38.6 \%$ & 7.1\% & $30.0 \%$ & $15.7 \%$ & $100.0 \%$ \\
\hline & & $\%$ of Total & $1.5 \%$ & $6.9 \%$ & $1.3 \%$ & $5.4 \%$ & $2.8 \%$ & $18.0 \%$ \\
\hline & $2-3$ years & Count & 5 & 21 & 7 & 25 & 15 & 73 \\
\hline & & $\begin{array}{l}\% \text { within } \\
\text { Duration_AIM }\end{array}$ & $6.8 \%$ & $28.8 \%$ & $9.6 \%$ & $34.2 \%$ & $20.5 \%$ & $100.0 \%$ \\
\hline & & $\%$ of Total & $1.3 \%$ & $5.4 \%$ & $1.8 \%$ & $6.4 \%$ & $3.9 \%$ & $18.8 \%$ \\
\hline & $>3$ years & Count & 25 & 66 & 25 & 59 & 22 & 197 \\
\hline & & $\begin{array}{l}\% \text { within } \\
\text { Duration_AIM }\end{array}$ & $12.7 \%$ & $33.5 \%$ & $12.7 \%$ & $29.9 \%$ & $11.2 \%$ & $100.0 \%$ \\
\hline & & $\%$ of Total & $6.4 \%$ & $17.0 \%$ & $6.4 \%$ & $15.2 \%$ & $5.7 \%$ & $50.6 \%$ \\
\hline \multirow[t]{2}{*}{ Total } & & Count & 42 & 127 & 48 & 119 & 53 & 389 \\
\hline & & $\%$ of Total & $10.8 \%$ & $32.6 \%$ & $12.3 \%$ & $30.6 \%$ & $13.6 \%$ & $100.0 \%$ \\
\hline
\end{tabular}

\section{Issue 1c: Problematic group member(s) in repayment of financing and} times of receiving AIM financing

This research further investigates the issue of problematic group members for repayment of financing based on different times of receiving AIM financing among the microentrepreneurs. Relying on the information shared by AIM officers, the period of financing will be extended together with the increment on the financing amount in case of the microentrepreneurs has successfully paid the initial financing on time without any issue. This research thus listed four different times of financing received by the microentrepreneurs which were; 1 time, 2 times, 3 times, and more than 3 times. As shown in Table 3c, out of 393 entrepreneurs that have received financing from AIM, 173 have agreed and strongly agreed that they have faced with this problem along the period of financing (44 percent). Overall, the highest percentage of agreement were 
recorded by those who have been given more than three (3) times of financing by AIM (25 percent).

Meanwhile, within the group, the highest number of agreement on this issue was recorded by the entrepreneurs that have received exactly 3 times of financing from AIM. These results indicate that the more period of financing given to the entrepreneurs, the tendency for them to face the issue of problematic group members to repay-back the financing which at the end bring to default of financing is high. This is serious matter to be concerned by the AIM which may affect the growth of the business of microentrepreneurs in future where they need to scarify their money to meet the default financing of other group members.

TABLE 5: Results of Cross-tabulation Analysis.

\begin{tabular}{|c|c|c|c|c|c|c|c|c|}
\hline \multicolumn{9}{|c|}{ Problematic group member(s) in repayment of financing and times of receiving AIM financing } \\
\hline & & & $\begin{array}{l}\text { Strongly } \\
\text { disagree }\end{array}$ & Disagree & Unsure & Agree & $\begin{array}{c}\text { Strongly } \\
\text { agree }\end{array}$ & \\
\hline \multirow[t]{12}{*}{ Times_fin } & 1 time & Count & 7 & 21 & 11 & 17 & 3 & 59 \\
\hline & & $\begin{array}{l}\% \text { within } \\
\text { Times_fin }\end{array}$ & $11.9 \%$ & $35.6 \%$ & $18.6 \%$ & $28.8 \%$ & $5.1 \%$ & $100.0 \%$ \\
\hline & & $\%$ of Total & $1.8 \%$ & $5.3 \%$ & $2.8 \%$ & $4.3 \%$ & $0.8 \%$ & $15.0 \%$ \\
\hline & 2 times & Count & 3 & 19 & 5 & 13 & 9 & 49 \\
\hline & & $\begin{array}{l}\% \text { within } \\
\text { Times_fin }\end{array}$ & $6.1 \%$ & $38.8 \%$ & $10.2 \%$ & $26.5 \%$ & $18.4 \%$ & $100.0 \%$ \\
\hline & & $\%$ of Total & $0.8 \%$ & $4.8 \%$ & $1.3 \%$ & $3.3 \%$ & $2.3 \%$ & $12.5 \%$ \\
\hline & 3 times & Count & 7 & 17 & 8 & 21 & 12 & 65 \\
\hline & & $\begin{array}{l}\% \text { within } \\
\text { Times_fin }\end{array}$ & $10.8 \%$ & $26.2 \%$ & $12.3 \%$ & $32.3 \%$ & $18.5 \%$ & $100.0 \%$ \\
\hline & & $\%$ of Total & $1.8 \%$ & $4.3 \%$ & $2.0 \%$ & $5.3 \%$ & $3.1 \%$ & $16.5 \%$ \\
\hline & $>3$ times & Count & 25 & 70 & 27 & 69 & 29 & 220 \\
\hline & & $\begin{array}{l}\% \text { within } \\
\text { Times_fin }\end{array}$ & $11.4 \%$ & $31.8 \%$ & $12.3 \%$ & $31.4 \%$ & $13.2 \%$ & $100.0 \%$ \\
\hline & & $\%$ of Total & $6.4 \%$ & $17.8 \%$ & $6.9 \%$ & $17.6 \%$ & $7.4 \%$ & $56.0 \%$ \\
\hline \multirow[t]{2}{*}{ Total } & & Count & 42 & 127 & 51 & 120 & 53 & 393 \\
\hline & & $\%$ of Total & $10.7 \%$ & $32.3 \%$ & $13.0 \%$ & $30.5 \%$ & $13.5 \%$ & $100.0 \%$ \\
\hline
\end{tabular}

\section{Issue 2a: Low discipline among group members and different educational background}

The second issue that was reported by the woman microentrepreneurs is on the low discipline among the group members that perhaps related to payment of financing, attendance to meeting, as well as committing with training. In this case, almost half of the respondents were agreed and strongly agreed (41.2 percent) on this issue (Table 4a). 
It is also found that the microentrepreneurs that belong to group of secondary school have agreed mostly over the total respondents (116 respondents over 393). In addition, within the group of education, it is observed that majority of the microentrepreneurs those were degree holders have agreed more than other groups (63.7 percent) even though they were small in number. Similar with the previous issue which related to attitude and behaviour of group members regarding the payment of financing, this issue was also become the concern of most of the microentrepreneurs that have higher educational background compared to lower education backgrounds.

TABLE 6: Results of Cross-tabulation Analysis.

\begin{tabular}{|c|c|c|c|c|c|c|c|c|}
\hline \multicolumn{9}{|c|}{ Low discipline among group members and different educational background } \\
\hline & & & $\begin{array}{l}\text { Strongly } \\
\text { disagree }\end{array}$ & Disagree & Unsure & Agree & $\begin{array}{c}\text { Strongly } \\
\text { agree }\end{array}$ & \\
\hline \multirow[t]{15}{*}{ Education } & $\begin{array}{l}\text { Primary } \\
\text { school }\end{array}$ & Count & 2 & 11 & 4 & 10 & 1 & 28 \\
\hline & & $\begin{array}{l}\% \text { within } \\
\text { Education }\end{array}$ & $7.1 \%$ & $39.3 \%$ & $14.3 \%$ & $35.7 \%$ & $3.6 \%$ & $100.0 \%$ \\
\hline & & $\%$ of Total & $0.5 \%$ & $2.8 \%$ & $1.0 \%$ & $2.5 \%$ & $0.3 \%$ & $7.1 \%$ \\
\hline & $\begin{array}{l}\text { Secondary } \\
\text { school }\end{array}$ & Count & 20 & 100 & 50 & 98 & 18 & 286 \\
\hline & & $\begin{array}{l}\% \text { within } \\
\text { Education }\end{array}$ & $7.0 \%$ & $35.0 \%$ & $17.5 \%$ & $34.3 \%$ & $6.3 \%$ & $100.0 \%$ \\
\hline & & $\%$ of Total & $5.1 \%$ & $25.4 \%$ & $12.7 \%$ & $24.9 \%$ & $4.6 \%$ & $72.8 \%$ \\
\hline & Certificate & Count & 5 & 11 & 2 & 9 & 1 & 28 \\
\hline & & $\begin{array}{l}\% \text { within } \\
\text { Education }\end{array}$ & $17.9 \%$ & $39.3 \%$ & $7.1 \%$ & $32.1 \%$ & $3.6 \%$ & $100.0 \%$ \\
\hline & & $\%$ of Total & $1.3 \%$ & $2.8 \%$ & $0.5 \%$ & $2.3 \%$ & $0.3 \%$ & $7.1 \%$ \\
\hline & Diploma & Count & 1 & 15 & 6 & 11 & 6 & 39 \\
\hline & & $\begin{array}{l}\% \text { within } \\
\text { Education }\end{array}$ & $2.6 \%$ & $38.5 \%$ & $15.4 \%$ & $28.2 \%$ & $15.4 \%$ & $100.0 \%$ \\
\hline & & $\%$ of Total & $0.3 \%$ & $3.8 \%$ & $1.5 \%$ & $2.8 \%$ & $1.5 \%$ & $9.9 \%$ \\
\hline & Degree & Count & 0 & 3 & 1 & 5 & 2 & 11 \\
\hline & & $\begin{array}{l}\% \text { within } \\
\text { Education }\end{array}$ & $0.0 \%$ & $27.3 \%$ & $9.1 \%$ & $45.5 \%$ & $18.2 \%$ & $100.0 \%$ \\
\hline & & $\%$ of Total & $0.0 \%$ & $0.8 \%$ & $0.3 \%$ & $1.3 \%$ & $0.5 \%$ & $2.8 \%$ \\
\hline \multirow[t]{2}{*}{ Total } & & Count & 28 & 140 & 63 & 134 & 28 & 393 \\
\hline & & $\%$ of Total & $7.1 \%$ & $35.6 \%$ & $16.0 \%$ & $34.1 \%$ & $7.1 \%$ & $100.0 \%$ \\
\hline
\end{tabular}

\section{Issue 2b: Low discipline among group members and different duration} with AIM

The issue of low discipline among the AIM members is further emphasised in terms of different duration of experiences among the microentrepreneurs dealt with AIM 
(Table 4b). Among the four different periods as previously discussed, most of the microentrepreneurs' understudy have dealt with AIM more than 3 years ( 80 have agreed on this issue). Overall, in terms of duration dealing with AIM, the agreement on this issue were mostly came from the respondents that have dealt with AIM between 12 years (47.2 percent agree and strongly disagree). It is followed by those who have dealt with AIM for a period of 2-3 years and more than 3 years. Compared to the previous issue, discipline issue was triggered earlier by the microentrepreneurs which is after a year of subscription with AIM Islamic microfinancing scheme. This indicate that low discipline among the group members is obviously seen and experienced even though by new members (1-2 years). Serious action need to be taken by AIM to ensure the cooperation system works smoothly without jeopardising the spirit of brotherhood among the members.

TABLE 7: Results of Cross-tabulation Analysis.

\begin{tabular}{|c|c|c|c|c|c|c|c|c|}
\hline \multicolumn{9}{|c|}{ Low discipline among group members and different duration dealt with AIM } \\
\hline & & & $\begin{array}{l}\text { Strongly } \\
\text { disagree }\end{array}$ & Disagree & Unsure & Agree & $\begin{array}{l}\text { Strongly } \\
\text { agree }\end{array}$ & \\
\hline \multirow[t]{12}{*}{ Duration_A } & $1<1$ year & Count & 5 & 17 & 10 & 14 & 3 & 49 \\
\hline & & $\begin{array}{l}\% \text { within } \\
\text { Duration_AIM }\end{array}$ & $10.2 \%$ & $34.7 \%$ & $20.4 \%$ & $28.6 \%$ & $6.1 \%$ & $100.0 \%$ \\
\hline & & $\%$ of Total & $1.3 \%$ & $4.4 \%$ & $2.6 \%$ & $3.6 \%$ & $0.8 \%$ & $12.6 \%$ \\
\hline & $1-2$ years & Count & 5 & 25 & 7 & 27 & 6 & 70 \\
\hline & & $\begin{array}{l}\% \text { within } \\
\text { Duration_AIM }\end{array}$ & 7.1\% & $35.7 \%$ & $10.0 \%$ & $38.6 \%$ & $8.6 \%$ & $100.0 \%$ \\
\hline & & $\%$ of Total & $1.3 \%$ & $6.4 \%$ & $1.8 \%$ & $6.9 \%$ & $1.5 \%$ & $18.0 \%$ \\
\hline & $2-3$ years & Count & 3 & 26 & 12 & 24 & 8 & 73 \\
\hline & & $\begin{array}{l}\% \text { within } \\
\text { Duration_AIM }\end{array}$ & $4.1 \%$ & $35.6 \%$ & $16.4 \%$ & $32.9 \%$ & $11.0 \%$ & $100.0 \%$ \\
\hline & & $\%$ of Total & $0.8 \%$ & $6.7 \%$ & $3.1 \%$ & $6.2 \%$ & $2.1 \%$ & $18.8 \%$ \\
\hline & $>3$ years & Count & 15 & 69 & 33 & 69 & 11 & 197 \\
\hline & & $\begin{array}{l}\% \text { within } \\
\text { Duration_AIM }\end{array}$ & $7.6 \%$ & $35.0 \%$ & $16.8 \%$ & $35.0 \%$ & $5.6 \%$ & $100.0 \%$ \\
\hline & & $\%$ of Total & $3.9 \%$ & $17.7 \%$ & $8.5 \%$ & $17.7 \%$ & $2.8 \%$ & $50.6 \%$ \\
\hline \multirow[t]{2}{*}{ Total } & & Count & 28 & 137 & 62 & 134 & 28 & 389 \\
\hline & & $\%$ of Total & $7.2 \%$ & $35.2 \%$ & $15.9 \%$ & $34.4 \%$ & $7.2 \%$ & $100.0 \%$ \\
\hline
\end{tabular}

Issue 2c: Low discipline among group members and times of receiving AlM financing

The study further investigates the issue of low discipline based on different times of receiving AIM financing among the microentrepreneurs. Based on results in Table 4c 
below, out of 393 entrepreneurs that have received financing from AIM, 162 have agreed and strongly agreed that they have faced with this problem along the period of financing (41.2 percent). In details, the highest percentage on agreement towards this issue were reported by those who have been given more than three (3) times of financing by AIM (94 respondents). Meanwhile, within the group, the highest number of agreement among the microentrepreneurs that were concerned on the same issue were those that have received exactly 3 times of financing from AIM (43.1 percent) and more (42.7 percent). This result is similar with the previous issue (problematic in repayment of financing) which indicates that the more times of financing given to the entrepreneurs, the tendency to face with the discipline issue among the AIM members is high.

TABLE 8: Results of Cross-tabulation Analysis.

\begin{tabular}{|c|c|c|c|c|c|c|c|c|}
\hline \multicolumn{9}{|c|}{ Low discipline among group members and times of receiving AIM financing } \\
\hline & & & $\begin{array}{l}\text { Strongly } \\
\text { disagree }\end{array}$ & Disagree & Unsure & Agree & $\begin{array}{c}\text { Strongly } \\
\text { agree }\end{array}$ & \\
\hline \multirow[t]{12}{*}{ Times_fin } & 1 time & Count & 4 & 24 & 8 & 19 & 4 & 59 \\
\hline & & $\begin{array}{l}\% \text { within } \\
\text { Times_fin }\end{array}$ & $6.8 \%$ & $40.7 \%$ & $13.6 \%$ & $32.2 \%$ & $6.8 \%$ & $100.0 \%$ \\
\hline & & $\%$ of Total & $1.0 \%$ & $6.1 \%$ & $2.0 \%$ & $4.8 \%$ & $1.0 \%$ & $15.0 \%$ \\
\hline & 2 times & Count & 4 & 18 & 10 & 12 & 5 & 49 \\
\hline & & $\begin{array}{l}\% \text { within } \\
\text { Times_fin }\end{array}$ & $8.2 \%$ & $36.7 \%$ & $20.4 \%$ & $24.5 \%$ & $10.2 \%$ & $100.0 \%$ \\
\hline & & $\%$ of Total & $1.0 \%$ & $4.6 \%$ & $2.5 \%$ & $3.1 \%$ & $1.3 \%$ & $12.5 \%$ \\
\hline & 3 times & Count & 5 & 19 & 13 & 24 & 4 & 65 \\
\hline & & $\begin{array}{l}\% \text { within } \\
\text { Times_fin }\end{array}$ & $7.7 \%$ & $29.2 \%$ & $20.0 \%$ & $36.9 \%$ & $6.2 \%$ & $100.0 \%$ \\
\hline & & $\%$ of Total & $1.3 \%$ & $4.8 \%$ & $3.3 \%$ & $6.1 \%$ & $1.0 \%$ & $16.5 \%$ \\
\hline & $>3$ times & Count & 15 & 79 & 32 & 79 & 15 & 220 \\
\hline & & $\begin{array}{l}\% \text { within } \\
\text { Times_fin }\end{array}$ & $6.8 \%$ & $35.9 \%$ & $14.5 \%$ & $35.9 \%$ & $6.8 \%$ & $100.0 \%$ \\
\hline & & $\%$ of Total & $3.8 \%$ & $20.1 \%$ & $8.1 \%$ & $20.1 \%$ & $3.8 \%$ & $56.0 \%$ \\
\hline \multirow[t]{2}{*}{ Total } & & Count & 28 & 140 & 63 & 134 & 28 & 393 \\
\hline & & $\%$ of Total & $7.1 \%$ & $35.6 \%$ & $16.0 \%$ & $34.1 \%$ & $7.1 \%$ & $100.0 \%$ \\
\hline
\end{tabular}

\section{Conclusion}

With the objective of identifying issues and challenges faced by the women microentrepreneurs of AIM and relating those issues with their different socio-demographic background, this study finds that most of the respondents are having issues with the group lending mechanism where concerns are highlighted about members' discipline and repayment of financing which is unfair for the other members. It is because, the 
group cooperation system that was practiced requires all members to be responsible towards each other especially for financing repayment. That is why in case of any of the members do not pay their weekly financing installment, the other members need to pay the installment of their behalf. This basically would bring issue of disbelief and dissatisfaction towards the system for the members that become victims caused by others' irresponsibility.

In particular, nearly half of them were agree that they have issue with their group members in terms of repayment of financing (44 percent agree and strongly agree) as well as low discipline of the members (41 percent). As a consequence, a few of them felt that the group lending mechanism that is practiced by AIM was ineffective (25.4 percent). In addition, by looking at the respondents' educational background, duration with AIM, and times of receiving financing from AIM, this research found that majority of the respondents that coming from higher education level, have dealt with AIM at least a year, and have received financing more than three times were concerned more on these issues compared to others.

Consequently, the study finds that the cooperation system that is currently practiced by AIM is still effective and applicable given that there are not many major issues reported by the microentrepreneurs. Respondents have not raised any issue regarding the product and services of AIM, but rather their concern is mainly on the financial discipline of the borrowers. Hence, this research would suggest AIM to enhance its cooperation system by utilizing technology to manage human and payment system in order to be fair to the clients.

\section{References}

[1] Al-Mamun, A., Malarvizhi, C., Hossain, S., \& Abdul Wahab, S. (2011). Examining the effect of participation in microcredit programs on assets owned by hardcore poor households in Malaysia. African Journal of Business Management, Vol. 5(22), 92869296.

[2] Haque, T., Siwar, C., Abdul Talib, B., Bhuiyan, A., \& Said, J. (2015). The Microfinance and Social Empowerment of the Women Borrowers of Amanah Ikhtiar Malaysia (Aim) In Malaysia. The Global Journal of Finance and Economics, 12(1), 1-19.

[3] Hawariyuni, W. and Gadar, K. (2015). Future and Challenges of Islamic Microfinance in Alleviating Poverty and Improving the Performance of Microenterprises: Evidence of Amanah Ikhtiar Malaysia (AIM), Malaysia. Australasian Journal of Islamic Finance and Business, 1(1), 31-61. 
[4] Mason, C., Azmi, W. N. W., \& Madden, R. (2018). Aiming for Greater Financial Inclusion through Sustainable Development: The Story of AIM (Amanah Ikthiar Malaysia). Asian Institute of Finance. Retrieved 15 April 2018 from http://www.aif.org.my/publications/ case-studies.

[5] Mokhtar, S. H., Nartea, G., \& Gan, C. (2012). The Malaysian microfinance system and a comparison with the Grameen Bank (Bangladesh) and Bank Perkreditan Rakyat (BPR-Indonesia). Journal of Arts and Humanities, 1(3), 60.

[6] Nawai, N. B., \& Bashir, M. S. (2007). Measuring Performance of Amanah Ikhtiar Malaysia (AIM) in Eradication Poverty. In The 2nd Islamic Conference.

[7] Nawai, N., \& Shariff, M. N. M. (2011). The importance of micro financing to the microenterprises development in Malaysia's experience. Asian Social Science, 7(12), 226.

[8] Saad, N. M., \& Duasa, J. (2011). An economic impact assessment of a microcredit program in Malaysia: the case of Amanah Ikhtiar Malaysia (AIM). International Journal of Business and Society, 12(1), 1.

[9] TEKUN. (2009). Operational reports 2009. Kuala Lumpur.

[10] Yayasan Usaha Maju Sabah. (2017). Sejarah Ringkas YUM. Yayasan Usaha Maju. http://www.yumsabah.com.my/my/index.php/mengenai-yum/sejarah-ringkasyum. Accessed 20 March 2017. 